Chapter 11

\title{
Development of Japanese Encephalitis Attenuated Live Vaccine Virus SA14-14-2 and its Charcteristics
}

Yongxin $\mathrm{Yu}$

Additional information is available at the end of the chapter

http://dx.doi.org/10.5772/ 52980

\section{Introduction}

Japanese encephalitis (JE) is the most common epidemic viral encephalitis in the world today. It is estimated that the JE virus causes at least 50,000 cases of clinical diseases each year resulting in about 10,000 deaths and 15,000 cases of long-term, neuro-psychiatric sequelae. In recent decades, outbreaks of JE have occurred in several previously non-endemic areas. Nearly 3 billion people live in JE-endemic regions, where more than 70 million children are born each year. For many years, only an inactivated JE vaccine made from infected mouse brain was licensed for use by residents and travelers. However, this vaccine proved to have an unacceptable levels of adverse safety events. Recently a safe and efficacious single-dose, liveattenuated vaccine (SA14-14-2) produced in China has become available to many Asian countries. It was higher immunogenicity, fewer doses of vaccination, less side reaction and cheaper than that of the world wide used mouse brain inactivated vaccine. Since it was licensed in 1989, the vaccine has been used in more than 300 million children with no vaccine-associated encephalitis case ever reported. Currently the vaccine is produced using specific pathogen free (SPF) hamster kidney cell (PHKC) in accordance with WHO technical specifications [47]. This paper reviews the development of the SA14-14-2 vaccine and its characteristics.

\subsection{Development of SA14-14-2 attenuated JE live vaccine}

\subsubsection{History of selecting attenuated vaccine virus SA14-14-2 strain}

The vaccine virus strain SA14-14-2 was derived from a wild-type Japanese encephalitis (JE) virus SA14 isolated from pool of Culex pipiens mosquito larvae in Xi'an, China. Attenuation was accomplished by serial passages of the SA14 virus in primary hamster kidney (PHK) cell culture at $36-37^{\circ} \mathrm{C}$. After 100 passages in PHK cells, followed by 3 times of plaque cloning, 
one clone 12-1-7 was selected from 36 plaque clones, which exhibited lower degree of virulence, $\mathrm{LD}_{50}>6.0 \log _{10} \mathrm{TCID}_{50}$ [25]. However its neuroattenuation was unstable and reverted to the virulence of parental SA14 after 1-2 mouse brain or several PHK cell passages [54]. The 12-1-7 clone was further plaque purified for 3 times and another 37 plaque clones were obtained. However those clones still showed unstable after 1-2 mouse brain passages. Then another method was performed for further attenuation. One selected virus clone (SA14-17-4) was peripherally passaged in non-neural tissues (spleen and skin) of mice followed by several times of plaque purification, which resulted in selecting an avirulent and highly stable virus clone, SA14-9-7. However, after human clinical trial, the SA14-9-7 strain showed low immunogenicity in vaccinated children (seroconversion $<10 \%[54]$ ). In order to promote immunogenicity, the SA14-9-7 virus was orally passaged six times in hamster, spleens harvested for two plaque purifications. One selected clone, SA14-5-3, demonstrated higher seroconversion rates in vaccinated children, $86.2 \%$ in JE endemic area[54] and 62\%in JE non-endemic area[2].The SA14-5-3 strain has been licensed for vaccine production and about five million children were vaccinated. SA14-5-3 vaccine was demonstrated to be safe but low protective efficacy, 64 - 93\% in humans in the clinical trial involving 400 thousand children [54].

\begin{tabular}{ll}
\hline Methods & Names \\
\hline SA 14 virus isolated from pool of Culex pipiens larvae by 11 passages in & (SA14) \\
mouse brain & $\begin{array}{l}\text { (SA14 clone } \\
12-1-7)\end{array}$ \\
\hline \hline 100 serial passages in PHK cells, followed by three plaque purifications in & (SA14 clone 17-4) \\
PCE cells & (SA14 clone 2) \\
\hline \hline Two plaque purifications in PCE cells & (SA14 clone \\
\hline One intraperitoneal passage in mice; harvesting of spleen for one plaque & $2-1-9)$ \\
\hline purification in PCE cells & (SA14 clone 9-7) \\
\hline Three plaque purifications in PCE cells & \\
\hline $\begin{array}{l}\text { One passage in mice, harvesting of skin and subcutaneous tissue for one } \\
\text { plaque purification in PCE cells }\end{array}$ & (SA14 clone 5-3) \\
\hline \hline Six oral passages in hamsters; harvesting of spleens for two plaque & \\
\hline \hline purifications in PHK cells & $\begin{array}{l}\text { (SA14 clone } \\
\text { Five passages in suckling mice; harvesting of skin and subcutaneous tissue }\end{array}$ \\
\hline for two plaque purifications in PHK cells & \\
\hline
\end{tabular}

Table 1. Attenuation history of Japanese encephalitis $\mathrm{SA}_{14}-14-2$ virus strainPCE: primary chick embryo; PHK: primary hamster kidney. * The notation SA14 clone 14-2 is abbreviated to SA14-14-2

To further promote immunogenicity, the SA14-5-3 virus was serially passaged by the subcutaneous route in suckling mice, using injected site skin and local lymph nodes for the subsequent passage materials. After cloning twice in PHK cells, the SA14-14-2 clone was selected [55]. This strain was equally attenuated compared to the SA14-5-3 but more immunogenic in mice, guinea-pigs, and pigs [55]. In human trials SA14-14-2 produced seroconversion rates greater than $90 \%$ in JE non-immune subjects living in JE non-endemic region [2]. Besides, 
Eckels et al. [7] adapted the SA14-14-2 virus to primary canine kidney cell cultures for 9 passages, SA14-14-2 PDK virus, which showed avirulent in mice and monkeys. However, SA14-14-2 PDK virus resulted in an unacceptably low neutralizing antibody response - $40 \%$ seroconversion rate - in childen in China [60]. The passage history is shown in Table1 and the characteristics of the various attenuated virus derivatives are shown in Table 2 and 3.

\begin{tabular}{lllllll}
\hline Virus/clones & \multicolumn{7}{l}{ Neurovirulence after different mouse brain passages } \\
\hline & 0 & 1 & 2 & 3 & 4 & 5 \\
\hline SA14 & $6.5^{\mathrm{a}}(-)^{\mathrm{b}}$ & $7.7(8.0)$ & - & - & - & - \\
\hline SA14-12-1-7 & $0(5.5)$ & $\geq 1.5(-)$ & $6.33(-)$ & - & - & - \\
\hline SA14-12-1-1 & $<0.0(7.5)$ & $2.50(6.5)$ & - & $6.00(7.00)$ & - & - \\
\hline SA14-9-4-2 & $<0.0(6.5)$ & $\leq 1.83(6.0)$ & - & $7.17 / 6.50$ & - & - \\
\hline SA14-17-4 & $0(-)$ & $\geq 4.5(\geq 4.5)$ & - & - & - & - \\
\hline SA14-2 & $0(-)$ & $0(-)$ & $<1.0(5.0)$ & $1.42(6.5)$ & $1.0(6.0)$ & $<1.0(6.5)$ \\
\hline SA14-2-1-9 & $0(4.5)$ & $0(\geq 6.5)$ & $0(5.0)$ & $<1.0(5.5)$ & $1.30(\geq 7.5)$ & $\geq 5.12(7.5)$ \\
\hline SA14-9-7 & $0(6.0)$ & $0(4.0)$ & $0(4.0)$ & $0(5.0)$ & $0(4.0)$ & $0(4.5)$ \\
\hline SA14-5-3 & $0(5.0)$ & $0(5.5)$ & $0.62(4.0)$ & $0(4.75)$ & $0.58(6.5)$ & $2.21(6.5)$ \\
\hline SA14-14-2 & $0(7.0)$ & $1.0(-)$ & $0.58(-)$ & $0.67(-)$ & $0.57(-)$ & $\leq 2.0(-)$ \\
\hline
\end{tabular}

Table 2. Neuroattenuation and its stability (reversibility) of various derivatives of attenuated strains from SA 14 virus strainsa., Intracereble (i.c.) inoculation tested in weanling mice, $\log _{10} \mathrm{LD}_{50} / 0.03 \mathrm{ml}$ b., $\log _{10} \mathrm{TCID}_{50} / 0.2 \mathrm{ml}$ - not determined

\begin{tabular}{|c|c|c|c|c|}
\hline \multirow{2}{*}{$\begin{array}{l}\text { Virus/ } \\
\text { clones }\end{array}$} & \multicolumn{2}{|c|}{ Neurovirulence $^{a}$} & \multirow[t]{2}{*}{ Reversibility $^{b}$} & \multirow[t]{2}{*}{ Immunogenicityc } \\
\hline & $\begin{array}{c}\text { Dose } \\
\left(\log _{10} p f u / m l\right)\end{array}$ & $\begin{array}{c}\log _{10} \mathrm{LD}_{50} / \mathrm{ml} \text { or No.dead } / \\
\text { no.tested }\end{array}$ & & \\
\hline $\mathrm{SA}_{14}$ & 8.78 & 8.50 & ND & ND \\
\hline $\mathrm{SA}_{14}-12-1-7$ & $7.7^{d}$ & 1.65 & + & ND \\
\hline $\mathrm{SA}_{14}-9-7$ & $6.70^{d}$ & $0 / 10$ & - & Low \\
\hline $\mathrm{SA}_{14}-5-3$ & 6.47 & $0 / 10$ & - & Moderate \\
\hline $\mathrm{SA}_{14}-14-2$ & 7.17 & $0 / 10$ & - & High \\
\hline $\mathrm{SA}_{14}-14-2$ & 6.25 & $0 / 10$ & ND & Moderate \\
\hline PDK & & & & \\
\hline
\end{tabular}

Table 3. Summary of the characteristics of various derivatives of attenuated strains from $\mathrm{SA}_{14}$ virus strainND not determined a) i.c. inoculation tested in weanling mice b) Reversion to neurovirulence of the parental $\mathrm{SA}_{14}$ virus in mice model: +, neuroreversion after one suckling mice or 1-2 weanling mice i.c. passages; -, no neuroreversion after mice i.c. passages. c) Neutralizing antibody seroconversion in humans: low, $<10 \%$; moderate, $40 \% \sim 60 \%$; high, $\geq 90 \%$. d) $\log _{10} \mathrm{TCID} 50 / \mathrm{ml}$

\subsection{Clinical studies}

Vaccine safety has been evaluated in several small-scale studies and in two large-scale studies in China. Studies of 588,512 children aged between 1 and 15 years inoculated with vac- 
cine from one manufacturer [35] and of 60000 children given vaccine from another manufacturer [15] reported no cases of temporally associated encephalitis. The most common adverse effect associated with vaccination was fever, which was reported in less than $0.2 \%$ of vaccinated children, with lower rates for rash and other systemic symptoms.

Daily examination of 867 vaccinated children for fever $\left(>38^{\circ} \mathrm{C}\right)$ disclosed low rates with onset distributed evenly over the 21-day observation period, without clustering as might have been expected if onset were associated with a specific incubation period. Temperature elevations were limited to a single day in most cases.

A block-randomized coherent study of 13,266 vaccinated and 12,951 nonvaccinated children followed prospectively for 30 days has shown that no cases of encephalitis or meningitis were detected in either groups, and rates of fever, allergic, respiratory symptoms were similar in the two groups [33]. Moreover no case of encephalitis associated with the live vaccine has been reported so far from the large scale vaccination in other areas of China [66] and in countries outside China [38, 4].The vaccine is well tolerated in subjects as young as 8 months.

The immunogenicity and protection efficacy in humans have been studied several times in China and outside China. Neutralizing antibody were produced in $85 \%$ 100\% of non-immune subjects studied in China [2, 58, 20,64] and 98\%, 92\% and 95\% studied in Korea [38], Philiphines [12] and Thailand [6], respectively after a single dose of vaccination. Several efficacy trials of SA14-14-2 vaccine in China from 1988 to 1999 in 1 to 10 year-old children have consistently yielded high protection rates, above 95\%,[66, 5, 43]. One study in Guizhou province [67] and another in Anhui province [66] have shown the protection efficacy persisted for at least 11 and 5 years respectively following an immunization schedule of one primary dose at one age and one booster dose at two ages. Case-control study for evaluation the efficacy of SA14-14-2 vaccine has been studied. A case control study conducted in 1993 in Sichuan province, China in children $<15$ years measured vaccine effectiveness of routinely delivered SA14-14-2 vaccine at $80 \%$ for a single-dose and $97.5 \%$ for a two-dose given at a one year interval [14]. In 1999, the SA14-14-2 vaccine was given as a single dose to over 220000 residents of the Terai region of Nepal in an effort to reduce the impact of an emerging epidemic of JE. A casecontrol study demonstrated $99.12 \%$ efficacy [4] followed by a 5-year efficacy of $96 \%$ [41]. In 2000, a case-control study in Chongqing city, China found a 93\% efficacy after one dose vaccination [42]. Besides, Kumar [23] reported a case control study in India, where 9.3 million children were immunized with SA14-14-2 vaccine in 2007 , demonstrated a $94.5 \%$ vaccine efficacy after a single dose.

\section{Phenotypic characteristic}

\subsection{In vitro phenotypic characteristics}

SA14-14-2 attenuated virus replicates well in primary hamster kidney (PHK) cell, C6/36 mosquito cells, continuous African green monkey kidney (Vero) cells, Rhesus monkey kidney $\left(\right.$ LLC-MK ${ }_{2}$ ) cells and baby hamster kidney (BHK21) cell lines. SA14-14-2 virus showed homogeneous small plaques $(\leq 1 \mathrm{~mm})$ when grown in above - mentioned cells, while SA14 wild strain showed heterogeneous and larger plagues (2-3mm) [57][1]. 
Many attenuated viruses are temperature-sensitive, often showing restricted growth in vitro at $39-40^{\circ} \mathrm{C}$, some strains were even sensitive to $37^{\circ} \mathrm{C}$. SA14-14-2 strain was not temperaturesensitive, showing no reduction in infectivity at $37^{\circ} \mathrm{C}$ or $40^{\circ} \mathrm{C}$. SA14-14-2 strain was also thermostable as the parental SA14 virus. In liquid status reduction of virus titer was $3.5 \log _{10}$ TCID50 after heated at $50^{\circ} \mathrm{C}$ for 50 minutes and virus could be detected 4 hours after further incubation at $50^{\circ} \mathrm{C}$, a result similar to that observed with SA14 parent strain. SA14-14-2 was more thermostabe than the SA14-5-3 [57].

\subsection{Ability of in vivo virus replication}

$\mathrm{Yu}$ et al. [55] studied the replication ability of SA14-14-2 virus in young mice (2.5 weeks) by subcutaneous (s.c.) inoculation followed by recovering virus from spleens and subcutaneous tissues of the infected mice for 2 weeks post inoculation. In those mice infected with the parent SA14 strain, viruses were recovered from the both tissues from day 4 to day 10 post infections, while those mice inoculated with SA14-14-2 strain, viruses were isolated in both tissues as well but limited within a short period from day 2 to day 4 or day 6 post infections (Table 4). Wu et al. [49] performed a similar study for recovering virus from brains and sera of the infected mice. Mice that infected with as less as $2.7 \log _{10} \mathrm{pfu} / \mathrm{mL}$ of the parent SA14 virus, high titers $\left(\geq 6.0 \log _{10} \mathrm{pfu} / \mathrm{mL}\right)$ of virus was detected in the brains and low titers $\left(2.7-3.4 \log _{10} \mathrm{pfu} / \mathrm{mL}\right)$ in the sera, whereas mice inoculated with as high as $6.2 \log _{10} \mathrm{pfu} /$ $\mathrm{mL}$ of the SA14-14-2, , virus was neither detected in the brains nor in the sera of the mice. Lee et al. [24] examined virus growth of SA14-14-2 live virus and the parent SA14 virus strains in mice after i.p. inoculation. The results showed that SA14 virus was detected in sera and in spleens with peak titers of $3.24 \log \mathrm{PFU} / \mathrm{ml}$ and $4.3 \log \mathrm{PFU} / \mathrm{g}$, respectively as well as brains with peak titer of $6.42 \log P F U / g$. On the other hand, SA14-14-2 virus was detected only in the spleens with extremely low titer $(1.7 \log P F U / m l)$ but not detected in the sera and brains of all ten inoculated mice.

\begin{tabular}{|c|c|c|c|c|c|c|c|c|}
\hline \multirow[t]{2}{*}{ Virus strain } & \multirow{2}{*}{$\begin{array}{l}\text { Infected virus titer } \\
\left(\log _{10} \mathrm{TCID}_{50} / \mathrm{mL}\right)\end{array}$} & \multirow{2}{*}{$\begin{array}{l}\text { Tissues } \\
\text { detected }\end{array}$} & \multicolumn{6}{|c|}{$\begin{array}{l}\text { Virus titers }\left(\log _{10} \mathrm{TCID}_{50} / \mathrm{mL}\right) \text { by days after } \\
\text { inoculation }\end{array}$} \\
\hline & & & 2 & 4 & 6 & 7 & 10 & $14-15$ \\
\hline \multirow[t]{2}{*}{ SA14-14-2 } & \multirow[t]{2}{*}{6.7} & $\begin{array}{l}\mathrm{SCa} \\
\text { tissue }\end{array}$ & 3.2 & 4.2 & 1.0 & ND & ND & ND \\
\hline & & spleen & 4.2 & 4.2 & 0 & ND & ND & ND \\
\hline \multirow{2}{*}{ SA14 } & \multirow{2}{*}{5.7} & SC tissue & ND & 2.7 & ND & $\geq 4.2$ & 0 & 0 \\
\hline & & spleen & ND & 2.2 & ND & $\geq 4.2$ & $\geq 3.2$ & 0 \\
\hline
\end{tabular}

Table 4. In vivo replication of SA14-14-2 strain in mice. a Subcutaneous tissue

Further investigation for viremia induction of SA14-14-2 virus using guinea pigs animal model has been studied by Liu et al [31]. Guinea pigs intraperitoneally (i.p.) injected with $4.0 \log _{10}$ $\mathrm{pfu} / \mathrm{mL}$ of parent virus SA14 and other 4 JEV virulent strains induced viremia to virus titers of $1.0-3.0 \log _{10} \mathrm{pfu} / \mathrm{mL}$ and lasted for 3 days post infection. However, the animals inoculated with SA14-14-2 strain containing virus titer equal to that of the virulent strains, no viremia was detected from day 1 to day 10 post inoculation (Table 5) 
Besides, a viremia clinical study in India has demonstrated the absence of any viremia activity in adult population up to 15 days after administration of a single dose of the live JE SA14-14-2 vaccine.

\begin{tabular}{|c|c|c|c|c|c|c|}
\hline \multirow[t]{2}{*}{ Virus strain } & \multirow{2}{*}{ Animal No. } & \multicolumn{5}{|c|}{$\begin{array}{l}\text { Viremia titer by day after inoculation } \\
\qquad\left(\log _{10} \mathrm{pfu} / \mathrm{mL}\right)\end{array}$} \\
\hline & & 1 & 3 & 5 & 7 & 10 \\
\hline \multirow{4}{*}{ P3 } & No.1 & 2.04 & 2.18 & 0 & ND & ND \\
\hline & No.2 & 2.08 & 2.59 & 0 & ND & ND \\
\hline & No.3 & 2.23 & 2.56 & 0 & ND & ND \\
\hline & No.4 & 1.70 & 2.21 & 0 & ND & ND \\
\hline \multirow{5}{*}{$02-41$} & No.1 & 1.00 & 1.78 & 0 & 0 & 0 \\
\hline & No.2 & 1.78 & 1.70 & 0 & 0 & 0 \\
\hline & No.3 & 1.78 & 1.60 & 0 & 0 & 0 \\
\hline & No.4 & 1.00 & 1.90 & 0 & 0 & 0 \\
\hline & No.5 & 1.30 & 1.95 & 0 & ND & ND \\
\hline \multirow{5}{*}{ HLJ02-144 } & No.1 & 1.90 & 1.30 & 0 & 0 & 0 \\
\hline & No.2 & 2.00 & 1.00 & 0 & 0 & 0 \\
\hline & No.3 & 1.95 & 1.48 & 0 & 0 & 0 \\
\hline & No.4 & 1.95 & 1.48 & 0 & 0 & 0 \\
\hline & No. 5 & 2.48 & ND & ND & ND & ND \\
\hline \multirow{5}{*}{ SA14 } & No.1 & 2.92 & ND & ND & ND & ND \\
\hline & No.2 & 2.41 & 2.85 & 0 & 0 & 0 \\
\hline & No.3 & 2.94 & 3.40 & 0 & 0 & 0 \\
\hline & No.4 & 2.53 & 3.00 & 0 & 0 & 0 \\
\hline & No.5 & 3.02 & ND & ND & ND & ND \\
\hline \multirow{5}{*}{ SA14-14-2 } & No.1 & 0 & 0 & 0 & 0 & 0 \\
\hline & No.2 & 0 & 0 & 0 & 0 & 0 \\
\hline & No.3 & 0 & 0 & 0 & 0 & 0 \\
\hline & No.4 & 0 & 0 & 0 & 0 & 0 \\
\hline & No.5 & 0 & 0 & 0 & 0 & 0 \\
\hline
\end{tabular}

Table 5. Viremia in guinea pigs after i.p. inoculation with different JEV virus strains. ND, Not determined

These results indicated that growth of the attenuated live virus in vivo was significantly reduced in contrast to the growth of parent SA14 virus, and SA14-14-2 strain showed a lack of viremia and neuroinvasion.

\subsection{Neuroattenuation phenotype}

Mice and rhesus monkeys are highly susceptible to the wild virulent Japanese encephalitis virus (JEV) inoculated by intracerebral route. Approximately 1 10 plaque forming unit (pfu) 
of the virus inoculated intracerebrally results in death. Mice are more susceptible than monkey to JE virus following inoculation by the peripheral route. Rhesus monkeys show four grades of response to the different attenuated JE viruses by i.c. inoculation [68]:

1. "death", the inoculation with parental SA14 virus;

2. "survival but showing neurological signs", i.e. the inoculation of SA14 $95^{\text {th }}$ PHK cell passage virus (SA14 HKC-95) ;

3. "survival, without showing neurological symptoms, but with fever" i.e. the inoculation with SA14-12-1-7 virus ;

4. "healthy", no fever, no symptom, no death, i.e. when the vaccine virus SA14-14-2 was inoculated.

Neurovirulence of JE SA14-14-2 strain was tested using these animal models with virus titers of $7.0 \sim 8.0 \log _{10} \mathrm{pfu} / \mathrm{ml}$. Weanling mice inoculated with the virus by i.c. or s.c. inoculation did not cause death. SA14-14-2 was tested by standard intrathalamic and intraspinal combination inoculation method in monkeys. Monkeys showed no mortality or morbidity and only a minimal degree of CNS inflammation around the injection sites [30] (Table 6). Further, neuropathogenicity was tested in immune- deficient or immune-suppressed animals, athymic nude mice or mice treated with cyclophosphamide. No deaths or histopathologic abnormalities were observed after intraperitoneal or subcutaneous inoculation of a viral dose greater than $10^{7.0} \mathrm{TCID} 50 / \mathrm{ml}$. Although cyclophosphamide increases susceptibility of mice to virulent JE strains, immunosuppression with cyclophosphamide did not lead to encephalitis in mice inoculated pheripherally with SA14-14-2 virus [56, 18]. The strain also did not kill weanling hamsters by i.c. inoculations [55].

\begin{tabular}{|c|c|c|c|c|c|c|}
\hline \multirow{2}{*}{$\begin{array}{c}\text { Virus } \\
\text { strain } \\
\text { (Virus titer, } \\
\text { pfu/ml) }\end{array}$} & \multirow[b]{2}{*}{$\begin{array}{l}\text { Inoculation } \\
\text { route }\end{array}$} & \multirow[b]{2}{*}{ Dilution } & \multicolumn{2}{|c|}{ Mice } & \multicolumn{2}{|c|}{ Rhesus Monkeys } \\
\hline & & & Died/tested & $\begin{array}{l}\text { Histopathological } \\
\text { score } \\
\text { (neuronal lesions) }^{\text {a }}\end{array}$ & Died/tested & $\begin{array}{c}\text { Histopathological } \\
\text { score } \\
\text { (neuronal lesions) }^{\mathrm{ab}}\end{array}$ \\
\hline \multirow{7}{*}{$\begin{array}{c}\text { SA14 } \\
\text { parent } \\
\left(6.15 \times 10^{8}\right)\end{array}$} & IC & $10-1$ & ND & ND & $2 / 2$ & $2-4$ \\
\hline & & $10-4$ & $8 / 8$ & $2-4$ & $0 / 1$ & $2-3$ \\
\hline & & $10-5$ & ND & ND & $2 / 2$ & $2-4$ \\
\hline & & $10-6$ & $8 / 8$ & $2-3$ & $2 / 2$ & $2-4$ \\
\hline & & $10-7$ & $8 / 8$ & $2-4$ & $2 / 2$ & $2-4$ \\
\hline & & $10-8$ & $8 / 8$ & $2-4$ & ND & ND \\
\hline & SC & $10-1$ & $30 / 30$ & 2-4(day 5) & ND & ND \\
\hline SA14-14-2( & IC & $1: 5$ & $0 / 30$ & $0-2$ & $0 / 4$ & $0-1$ \\
\hline $\left.8 \times 10^{6}\right)$ & SC & $1: 5$ & $0 / 30$ & $0(1)^{c}$ & ND & ND \\
\hline
\end{tabular}

Table 6. Comparative neurovirulence of attenuated SA14-14-2 and parent SA14 Japanese encephalitis viruses in 3week-old mice and adult rhesus monkeysIC, intracerebral; SC, subcutaneous. ND, Not determineda) 0, No lesion; 1 , $\leq 5 \% ; 2,6-20 \% ; 3,21-50 \% ; 4,>50 \%$ of neurons died.b) Inoculation in thalami bilaterally (each $0.5 \mathrm{ml}$ ) and lumbar spinal cord $(0.2 \mathrm{~mL}) . \mathrm{c})$ One mouse showed a few dead nerve cells. 


\section{4. phenotypic stabilities}

\subsubsection{Stability of plaque morphology}

Small homogeneous plaque $(\leq 1 \mathrm{~mm})$ morphology was retained through 8 -17 PHK cell passages studied by Jia et al. [17]. As reported by Aihara, plaque-size phenotypes did not change during plaque purification in $\mathrm{BHK}_{21}$ cells and propagation in C6/36 cell [1]. Eckels et al. [7] showed that SA14-14-2 strain had a homogeneous small plaque morphology, with no large plaques seen when passed 7 times in LLC-MK ${ }_{2}$ cells.

\subsubsection{Stability of neuroattenuation}

Wang et al. [44] studied neuroattenuation stability by serial passages the SA14-14-2 strain from passage 8 to passage 23 in PHK cells, virulence was tested every 2-3 passages by intracerebral or subcutaneous inoculation in mice $(12 \sim 14 \mathrm{~g})$. None of the PHK-passaged viruses containing virus doses of 8.0 9.0 $\log _{10}$ TCID50 caused death in these mice. Jia et al. [16] passed the SA14-14-2 virus in PHK cells for 17 passages, neurovirulence and neuroinvasion were determined at the $8^{\text {th }}, 15^{\text {th }}, 17^{\text {th }}$ passage. No animal showed illness at any the passage level.

Eckels et al. [7] performed the neuroattenuation stability by serial passage the SA14-14-2 virus in Beagle canine kidney cells for a total of 15 passages, the passage 15 virus was attenuated for young mice causing no symptoms or death by i.c. inoculation. Wang et al. [45] passaged the SA14-14-2 HKC5 virus in primary dog fetal kidney cell cultures for 11 passages. Each of the passaged virus was tested for its pathogenicity in weanling mice, all the mice survived by either i.c. or s.c. inoculation with a virus dose containing 7.5-8.0 $\log _{10}$ TCID50/0.2ml. These results showed that over many passages of the SA14-14-2 virus in PHK cells or primary dog kidney cells, neuroviruence reversed to the virulence of parental SA14 was not observed.

Wu et al [49] studied on the stability of SA14-14-2 vaccine seed virus by i.c. passage in suckling mice, viruses recovered from the mice brain of passage 1 only caused a few weanling mice death following i.c. inoculation with a high dose of $8.7 \log _{10} \mathrm{pfu} / \mathrm{ml}$ virus (LD50 $\geq 7.7$ $\log _{10} \mathrm{pfu}$ ), showing no reversion to the virulence of SA14 parent virus (i.c.LD50 $\geq 0.28$ $\left.\log _{10} \mathrm{pfu}\right)$.

Athymic nude mice (nu/nu) inoculated intra-peritoneally with $8.2 \log _{10}$ TCID50/ml of SA14-14-2 virus did not fall ill. Attempts to recover virus from brain, liver, spleen, kidney, heart and lymph nodes were made over a period of 3 weeks. In three independent experiments viruses were recovered only in one experiment from brain at the $10^{\text {th }}, 14^{\text {th }}$ and $21^{\text {st }}$ day and kidney tissue at $6^{\text {th }}$ day. Virus isolated from the brains on day $21^{\text {st }}$ after intraperitoneal inoculation, was enhanced once in PHK cell to a virus titers of 6.7-7.2 $\log _{10} \mathrm{TCID}_{50} / \mathrm{ml}$ and then tested for neurovirulence and neuroinvasiveness in normal mice. Tests were repeated three times and showed that the recovered viruses were avirulent to $10-12 \mathrm{~g}$ mice by i.c. or intraperitoneal inoculation, maintaining the attenuated phenotype as SA14-14-2 [56]. 
Neuroattenuation after long-term cold storage has been studied. Fourteen lots of lyophilized live JE vaccines manufactured year by year since 1987 were stored at low temperature $\left(-20^{\circ} \mathrm{C}\right)$. After 15 years, neurovirulence of the vaccine viruses were studied in year 2002. The results showed that viruses in the all 14 lots were avirulent for i.c. inoculated mice. [22]

\subsection{Growth characteristics and ability of transmission in mosquitoes}

Mosquito infection and transmission with SA14-14-2 virus have been done using Culex tritaeniorhynchus mosquitoes, the most important JEV vector species, by oral feeding with meals containing the virus or intrathoracial(IT) inoculation with the virus. The mosquitoes did not become infected by oral feeding with meals containing $6.06 \log _{10} \mathrm{pfu} / \mathrm{ml}$ virus and only one of the 34 groups (3.13\%) of the infected mosquitoes became infected after feeding with meals containing $6.18 \log _{10} \mathrm{pfu} / \mathrm{ml}$ virus, reaching a low virus titer of $1.24 \log _{10} \mathrm{pfu} / \mathrm{ml}$. However, most of the mosquitoes (10 of 14 groups, $71.43 \%$ ) became infected after feeding meals containing $7.85 \log _{10} \mathrm{pfu} / \mathrm{ml}$ of virulent JE virus strain Nakayama(Nak), reaching higher titers of 3.33-4.79 $\log _{10} \mathrm{pfu} / \mathrm{ml}$ (Table 7) [62]. The result indicated that SA14-14-2 virus is restricted in its ability to infect and replicate in the Culex tritaeniorhychus mosquito vector.

\begin{tabular}{lllll}
\hline \multirow{2}{*}{ Virus strain } & $\begin{array}{l}\text { Meals containing } \\
\text { virus( }\left(\log _{10} p \mathbf{p u} / \mathrm{ml}\right)\end{array}$ & $\begin{array}{l}\text { No. groups } \\
\text { tested }\end{array}$ & $\begin{array}{l}\text { Total number of } \\
\text { mosquitoes } \\
\text { tested }\end{array}$ & No. group Positive (\%) \\
\hline \multirow{2}{*}{ SA14-14-2 } & 6.06 & $15(4-31)^{1}$ & $345(15-36)^{2}$ & $0(0 \%)$ \\
\cline { 2 - 5 } & 6.18 & $34(2-11)$ & $573(10-39)$ & $1(3.13 \%)(1.24)^{3}$ \\
\hline Nakayama & 7.85 & $14(3-11)$ & $215(11-26)$ & $10(71.43 \%)(3.33-4.79)$ \\
\hline
\end{tabular}

Table 7. Growth of SA14-14-2 virus and wild virulent JEV Nak strain in Culex tritaeniorhynchus mosquitoes by oral infections.

Mosquitoes were exposed to virus-containing meals for oral ingestion. Fully engorged mosquitoes were then collected after a period of extrinsic incubation.

1. Times(days) of extrinsic incubation periods;

2. Numbers of mosquito per group;

3. Virus titers in the mosquito suspensions of the positive groups $\left(\log _{10} \mathrm{pfu} / \mathrm{ml}\right)$

However, virus could replicate at low level by intrathoracical (I.T.) inoculation of the Cx.tritaeniorhynchus mosquitoes [62], reaching titers of $2.0 \sim 3.72 \log _{10} \mathrm{pfu} / \mathrm{ml}$ over $2 \sim 20$ days after inoculation. In contrast, mosquitoes IT infected with its parent SA14 virus exhibited higher ability of replication, reaching titers of 3.0 4.85 $\log _{10} \mathrm{pfu} / \mathrm{ml}$ over the same periods [10].

The ability of transmission by the IT infected mosquitoes was studied later. Two groups of the mosquitoes were infected IT with SA14-14-2 virus, 8 days after infection one group of infected mosquitoes was used to infect suckling mice by direct bite, another group of infected mosquitoes was made in a suspension (M-1), in which the virus content was measured, 
and used to infect weanling mice by i.c. inoculation. In order to enhance the virus titer of the mosquito suspension (M-1), it was passed once in BHK cells (M-1 C-1) and then infected mice by i.c. and s.c. inoculation. The full E protein gene of the M-1 C-1 virus was sequenced and compared to that of its parent SA14-14-2 virus. As shown in Table 8, none of the mice died after bitten or i.c. inoculation with virus titers of 4.2 and $7.2 \log _{10} \mathrm{pfu} / \mathrm{ml}$, and only one nucleotide in the virus $\mathrm{E}$ protein gene changed resulting in one amino acid substitution $(\mathrm{E} 447 \mathrm{~A} \rightarrow \mathrm{G})$ which was not reverse mutation. And the eight critical amino acids remained unchanged. The similarity of the virus full E gene sequence compared to that of the parent SA14 was $99.9 \%$ [34]. This result demonstrated that the SA14-14-2 virus is phenotypic and genetic stable and could not be transmitted after mosquito passage.

\begin{tabular}{|c|c|c|c|c|c|c|c|c|}
\hline \multirow[t]{2}{*}{ Virus $^{\mathrm{a}}$} & \multirow{2}{*}{$\begin{array}{l}\text { Virus titer } \\
\text { Pfu/ml }\end{array}$} & \multicolumn{4}{|c|}{$\begin{array}{l}\text { Virulence tested in } \\
\text { Suckling mice } 2.5 \text { weeks mice }\end{array}$} & \multicolumn{3}{|c|}{ E gene sequence } \\
\hline & & bitten $^{b}$ & ic & ic & sc & & tion & similarity \\
\hline $\mathrm{SA}_{14}-14-2 \mathrm{M}-1$ & $10^{4.2}$ & $0 / 16^{c}$ & $0 / 16$ & & & & & \\
\hline$M-1 C-1$ & $10^{7.2}$ & & & $0 / 10$ & $0 / 10$ & $0 / 8^{d}$ & $\begin{array}{l}E-447 \\
(A \rightarrow G)\end{array}$ & $99.9 \%$ \\
\hline
\end{tabular}

Table 8. Virulence and $\mathrm{E}$ gene sequence of the $\mathrm{SA}_{14}-14-2$ virus after Culex tritaeniorhynchus mosquitoes IT passage. a One intrathoracical passage (SA $14-14-2 \mathrm{M}-1)$ and one BHK-21 cell passage (M-1 C-1).b By the infected mosquitoes C No. dead /no. testedd No. reversion/no. attenuating amino acidSC Subcutaneously

\section{Genotypic characteristics}

\subsection{Gene sequence of SA14-14-2 compared to its parent SA14 and other attenuated derivatives.}

When the full-length gene sequence of $\mathrm{SA}_{14}-14-2$ was compared to parental $\mathrm{SA}_{14}, 57-66 \mathrm{nu}$ cleotide substitutions were found to be scattered all over the genome except prM. These coded for 24-31 amino acid substitutions, of which 8 were in E protein[1, 61] and were studied to be the critical amino acid mutations involved in virus attenuation [3, 13] (Table 9). Among the 8 substituted amino acids observed in SA14-14-2 virus, only 3 substitutions appeared in the unstable virus SA14-12-1-7; while those highly and stable strains, $\mathrm{SA}_{14}-9-7$, $\mathrm{SA}_{14}-5-3$ and $\mathrm{SA}_{14}-14-2$ PDK viruses had 6 changes of the 8 amino acids [Ni $\mathrm{H}$ et al.,1994, 8]. Two of the 8 amino acid substitutions at position E-177 (T,Threonine $\rightarrow$ A,Alanine) and E-264 $\left(\mathrm{Q}\right.$, Glutamine $\rightarrow \mathrm{H}$, Histudine) were unique to $\mathrm{SA}_{14}-14-2$ virus [8] (Table 10). The contribution of these two amino acid changes to the biological properties of $\mathrm{SA}_{14}-14-2$ virus requires further study. 


\begin{tabular}{|c|c|c|c|c|}
\hline \multicolumn{2}{|c|}{ Position } & \multicolumn{2}{|c|}{ SA14-14-2 } & \multirow{2}{*}{ SA14 } \\
\hline aа & $\mathrm{nt}$ & Zeng & Aihara & \\
\hline C-65 & 292 & $S$ & $S$ & $L$ \\
\hline E-107 & 1296 & $\mathrm{~F}$ & $\mathrm{~F}$ & L \\
\hline E-138 & 1389 & K & K & E \\
\hline E-176 & 1503 & V & V & I \\
\hline E-177 & 1506 & $A$ & $A$ & $T$ \\
\hline E-264 & 1769 & $\mathrm{H}$ & $\mathrm{H}$ & Q \\
\hline$E-279$ & 1813 & M & $M$ & $\mathrm{~K}$ \\
\hline E-315 & 1921 & V & V & $A$ \\
\hline$E-334$ & 1977 & $P$ & $S$ & $S$ \\
\hline E-439 & 2293 & $\mathrm{R}$ & $\mathrm{R}$ & K \\
\hline NS1-292 & 3351 & $S$ & $S$ & G \\
\hline NS1-339 & 3493 & M & M & $\mathrm{R}$ \\
\hline NS1-351 & 3528 & $\mathrm{H}$ & $\mathrm{H}$ & $D$ \\
\hline NS1-354 & 3539 & $\mathrm{~K}$ & $\mathrm{~K}$ & $\mathrm{~N}$ \\
\hline NS1-392 & 3652 & V & V & $A$ \\
\hline NS2B-63 & 4403 & $D$ & D & E \\
\hline NS2B-65 & 4408 & G & G & $D$ \\
\hline NS2B-87 & 4475 & $\mathrm{~F}$ & L & L \\
\hline NS3-59 & 4782 & V & V & M \\
\hline NS3-73 & 4825 & K & K & $\mathrm{R}$ \\
\hline NS3-105 & 4921 & G & G & $A$ \\
\hline NS3-343 & 5634 & $\mathrm{R}$ & W & $\mathrm{R}$ \\
\hline NS4A-27 & 6634 & I & $\mathrm{T}$ & I \\
\hline NS4B-106 & 7227 & V & V & I \\
\hline NS5-31 & 7768 & G & A & $A$ \\
\hline NS5-45 & 7809 & S & $\mathrm{R}$ & $\mathrm{R}$ \\
\hline NS5-195 & 8261 & I & M & M \\
\hline NS5-386 & 8832 & Y & $Y$ & $\mathrm{H}$ \\
\hline NS5-636 & 9593 & $\mathrm{H}$ & Q & Q \\
\hline NS5-671 & 9688 & A & A & V \\
\hline NS5-731 & 9898 & G & $D$ & $D$ \\
\hline NS5-759 & 9954 & $P$ & A & $A$ \\
\hline NS5-767 & 9978 & V & L & L \\
\hline
\end{tabular}

Table 9. Comparison of amino acid differences between JE attenuated vaccine SA14-14-2 and its parent SA14 strain reported by Aihare and Zeng

Sequences were reported by [1] and [61] 


\subsection{Stability of gene sequence of SA14-14-2 virus strain}

SA14-14-2 virus at PHK cells passage $8\left(\mathrm{PHK}_{8}\right)$ was serially passed to $\mathrm{PHK} 17$ or given one i.c. passage in suckling mouse $\left(\mathrm{HKC}_{8} \mathrm{SM}_{1}\right)$. The E protein gene of the viruses was sequenced and compared to that of SA14-14-2 $\mathrm{PHK}_{8}$ and parental $\mathrm{SA}_{14}$. At passage 17, all the 8 attenuating amino acid residues in SA14-14-2 $\mathrm{PHK}_{8}$ were retained no change, while two new nucleotide mutations were found at NT-1970 $\left(\mathrm{T}^{\cdot} \cdot \mathrm{G}\right)$, and NT-2169 $(\mathrm{A} \cdot \mathrm{G})$, which resulted in two amino acid changes at positions E-331 (S * R) and E-398 (K • E)( Table 11). The two substituted amino acids, $\operatorname{Arg}(\mathrm{R})$ and $\mathrm{Glu}(\mathrm{E})$, were not the residues of parental SA14, Ser(S) and Lys(K), this suggests that the two changes were not reverse mutation [9]. After one passage of the $\mathrm{PHK}_{8}$ virus in suckling mouse brain (SA14-14-2 $\mathrm{HK}_{8} \mathrm{SM}_{1}$ ), 7 of the 8 amino acids remained unchanged, one at E107 $(\mathrm{F} \rightarrow \mathrm{L})$ was reverse mutation, while 3 other amino acid mutations appeared at E-83, E-318 and E-327, which were not reverse mutations (Table 11).

\begin{tabular}{ccccccccc}
\hline Virus & \multicolumn{7}{c}{ Mutation sites } \\
\cline { 2 - 9 } & 107 & 138 & 176 & 177 & 264 & 279 & 315 & 439 \\
\hline $\mathrm{SA}_{14}-14-2 \mathrm{PHK}$ & $\mathrm{F}$ & $\mathrm{K}$ & $\mathrm{V}$ & $\mathrm{A}$ & $\mathrm{H}$ & $\mathrm{M}$ & $\mathrm{V}$ & $\mathrm{R}$ \\
\hline $\mathrm{SA}_{14}-12-1-7$ & $\mathrm{~F}$ & $\mathrm{E}$ & $\mathrm{V}$ & $\mathrm{T}$ & $\mathrm{Q}$ & $\mathrm{K}$ & $\mathrm{A}$ & $\mathrm{R}$ \\
\hline $\mathrm{SA}_{14}-9-7$ & $\mathrm{~F}$ & $\mathrm{~K}$ & $\mathrm{~V}$ & $\mathrm{~T}$ & $\mathrm{Q}$ & $\mathrm{M}$ & $\mathrm{V}$ & $\mathrm{R}$ \\
\hline $\mathrm{SA}_{14}-5-3$ & $\mathrm{~F}$ & $\mathrm{~K}$ & $\mathrm{~V}$ & $\mathrm{~T}$ & $\mathrm{Q}$ & $\mathrm{M}$ & $\mathrm{V}$ & $\mathrm{R}$ \\
\hline $\mathrm{SA}_{14}-14-2 \mathrm{PDK}$ & $\mathrm{F}$ & $\mathrm{K}$ & $\mathrm{V}$ & $\mathrm{T}$ & $\mathrm{Q}$ & $\mathrm{M}$ & $\mathrm{V}$ & $\mathrm{R}$ \\
\hline Parental SA $_{14}$ & $\mathrm{~L}$ & $\mathrm{E}$ & $\mathrm{I}$ & $\mathrm{T}$ & $\mathrm{Q}$ & $\mathrm{K}$ & $\mathrm{A}$ & $\mathrm{K}$ \\
\hline
\end{tabular}

Table 10. Comparison of the amino acid differences in the E protein gene of JE SA $\mathrm{A}_{14}-14-2$ PHK vaccine virus with the other attenuated derivatives and the parental SA14

\begin{tabular}{ccccc}
\hline \multirow{2}{*}{ Site } & SA $_{\mathbf{1 4}} \mathbf{V}_{\mathbf{2}}$ & & SA14-14-2 & \\
\cline { 3 - 5 } & & $\mathbf{H K C}_{\mathbf{8}} \mathbf{V}_{\mathbf{2}}$ & $\mathbf{H K C}_{\mathbf{1 7}} \mathbf{V}_{\mathbf{2}}$ & $\mathbf{H K C}_{\mathbf{8}} \mathbf{S M}_{\mathbf{1}}$ \\
\hline $\mathrm{E}-83$ & $\mathrm{E}$ & $\mathrm{E}$ & $\mathrm{E}$ & $\mathrm{Q}$ \\
\hline $\mathrm{E}-107$ & $\mathrm{~L}$ & $\mathrm{~F}$ & $\mathrm{~F}$ & $\mathrm{~L}$ \\
\hline $\mathrm{E}-138$ & $\mathrm{E}$ & $\mathrm{K}$ & $\mathrm{K}$ & $\mathrm{K}$ \\
\hline $\mathrm{E}-176$ & $\mathrm{H}$ & $\mathrm{V}$ & $\mathrm{V}$ & $\mathrm{V}$ \\
\hline $\mathrm{E}-177$ & $\mathrm{~T}$ & $\mathrm{~A}$ & $\mathrm{~A}$ & $\mathrm{~A}$ \\
\hline $\mathrm{E}-264$ & $\mathrm{Q}$ & $\mathrm{H}$ & $\mathrm{H}$ & $\mathrm{H}$ \\
\hline $\mathrm{E}-279$ & $\mathrm{~K}$ & $\mathrm{M}$ & $\mathrm{M}$ & $\mathrm{M}$ \\
\hline $\mathrm{E}-315$ & $\mathrm{~A}$ & $\mathrm{~V}$ & $\mathrm{~V}$ & $\mathrm{~V}$ \\
\hline $\mathrm{E}-318$ & $\mathrm{G}$ & $\mathrm{G}$ & $\mathrm{G}$ & $\mathrm{D}$ \\
\hline $\mathrm{E}-327$ & $\mathrm{~S}$ & $\mathrm{~S}$ & $\mathrm{~S}$ & $\mathrm{~F}$ \\
\hline $\mathrm{E}-331$ & $\mathrm{~S}$ & $\mathrm{~S}$ & $\mathrm{R}$ & $\mathrm{S}$ \\
\hline $\mathrm{E}-398$ & $\mathrm{~K}$ & $\mathrm{~K}$ & $\mathrm{E}$ & $\mathrm{K}$ \\
\hline $\mathrm{E}-439$ & $\mathrm{~K}$ & $\mathrm{R}$ & $\mathrm{R}$ & $\mathrm{R}$ \\
\hline
\end{tabular}

Table 11. Substitutions of amino acid of SA14-14-2 strain after passage in PHK cell or suckling mice. $H_{K} C_{8} V_{2}, H K C 8$ passages, vero cells 2 passages ; $\mathrm{HKC}_{17} \mathrm{~V}_{2}, \mathrm{HKC} 17$ passages, vero cells 2 passages ; $\mathrm{HKC}_{8} \mathrm{SM}_{1}, \mathrm{HKC} 8$ passages, suckling mice one i.c. passage 
Li et al. [27] and Gao et al.[11] performed similar studies by additional passage of the SA14-14-2 vaccine seed virus (early passage) in PHK cell culture to passage 20 and passage 18, respectively. The E protein gene sequences of the various passaged viruses were sequenced and compared to the original seed virus.The results demonstrated no reverse mutation of the 8 attenuating amino acids.

$\mathrm{Xu}$ et al [52] studied full-length sequence stability of the SA14-14-2 virus by passing the early passages seed virus $\left(\mathrm{PHK}_{8}\right)$ on $\mathrm{PHK}$ cells to passage $22\left(\mathrm{PHKC}_{22}\right)$ and its full-length genome was sequenced. By comparing the full sequences of the $\mathrm{PHKC}_{22}$ with the original primary seed virus of SA14-14-2 in Genbank (D90195), the result showed that there were only 8 nucleotide differences (one in E, 5 in non-structure-region and 2 in 3'-NTR) leading to 4 amino acids changed, which were not reverse mutations. The homology of the nucleotides and amino acids between the viruses of passage 22 viruses and the primary seed virus in Genbank was $99.93 \%$ and $99.88 \%$, respectively (Table 12). These results demonstrated that the genotype of SA14-14-2 vaccine virus was very stable during multiple cell culture passages.

\begin{tabular}{|c|c|c|c|}
\hline \multicolumn{2}{|c|}{ Position } & \multirow[t]{2}{*}{ Nucleotide change } & \multirow[t]{2}{*}{ Amino acid change } \\
\hline $\mathrm{Nt}$ & $\mathrm{Aa}$ & & \\
\hline 2142 & E-389 & $a \rightarrow c$ & $\mathrm{D} \rightarrow \mathrm{N}$ \\
\hline 3929 & NS2a-69 & $t \rightarrow c$ & none \\
\hline 5634 & NS3-343 & $t \rightarrow a$ & $W \rightarrow R$ \\
\hline 6634 & NS4a-57 & $c \rightarrow t$ & $\mathrm{~T} \rightarrow \mathrm{I}$ \\
\hline 7655 & NS4b-130 & $g \rightarrow t$ & none \\
\hline 9593 & NS5-639 & $g \rightarrow t$ & $\mathrm{Q} \rightarrow \mathrm{H}$ \\
\hline 10701(3'-NCR) & & $-\rightarrow g$ & \\
\hline 10784(3'-NCR) & & $t \rightarrow c$ & \\
\hline
\end{tabular}

Table 12. Nucleotide and amino acid changes in the PHK cells passage 22 compared to the sequence of SA14-14-2 in Genbank (D90195)

\section{Immunogenicity}

\subsection{Humoral immune response}

Wills et al. [48] investigated the ability of SA14-14-2 (PHK) and other 4 attenuated vaccine clones SA14-2-8, SA14-5-3, SA14-14-2 (PDK) to induce a humoral immune response in Balb/c mice. The mice, 6-8 weeks old, were inoculated by intraperitoneal route with $10^{3}$ and $10^{6} \mathrm{pfu}$ of the live viruses. Mice were bled 14 and 28 days postinoculation. Anti-JE serum antibody levels were measured using hemagglutination inhibition (HAI) and neutralization (N) tests. The results demonstrated that the live SA14-14-2 (PHK) elicited good HAI and N responses at dose of $10^{3}$ and $10^{6} \mathrm{pfu}$ at 14 days postinoculation, with the 28-days sera showing no reduction in $\mathrm{N}$ titer. In comparison, $10^{6} \mathrm{pfu}$ of the SA14-14-2 (PDK) virus evoked only a poor $\mathrm{N}$ response by 14 days postinoculation and neutralizing antibody was not detectable with a 
dose of $10^{3}$ pfu either 14 or 28 days postinoculation (titre $\leq 20$ ). The two early vaccine clones SA14-2-8 and SA14-5-3 both produced results very similar to SA14-14-2 (PDK) in terms of $\mathrm{HAI}$ and $\mathrm{N}$ responses at the given dose (Table 13).

Lee et al. [24] reported that mice vaccinated with one dose of SA14-14-2 virus (4.0 $\log _{10} \mathrm{pfu} / \mathrm{ml}$ ) produced $\mathrm{N}$ antibody (titer 1:60), HAI antibody(22.2), complement fixation (CF) antibody (11.2) and were protected against a lethal JEV i.c. challenge (90\% protection). Meanwhile, the anti-NS1(non-structural NS1) antibody was detected in sera of the vaccinated mice, which may also be responsible for the protection.

\begin{tabular}{|c|c|c|c|c|c|c|c|c|}
\hline \multirow{3}{*}{ Virus strains } & \multicolumn{4}{|c|}{ Titre at day 14 for dose $\left(\log _{10} p f u\right)$} & \multicolumn{4}{|c|}{ Titre at day 28 for dose $\left(\log _{10} p f u\right)$} \\
\hline & \multicolumn{2}{|c|}{3} & \multicolumn{2}{|c|}{6} & \multicolumn{2}{|c|}{3} & \multicolumn{2}{|c|}{6} \\
\hline & $\mathrm{N}$ & $\mathrm{HAl}$ & $\mathrm{N}$ & $\mathrm{HAl}$ & $\mathrm{N}$ & $\mathrm{HAl}$ & $\mathrm{N}$ & $\mathrm{HAl}$ \\
\hline SA14-14-2(PHK) & 320 & 320 & 640 & 80 & 320 & NT & 640 & 320 \\
\hline SA14-14-2(PDK) & $<20$ & 40 & 80 & 320 & $<20$ & 160 & 80 & NT \\
\hline SA14-2-8 & 80 & NT & 160 & NT & 160 & NT & 160 & NT \\
\hline SA14-5-3 & 40 & NT & 80 & NT & 160 & NT & 160 & NT \\
\hline
\end{tabular}

Table 13. Humoral immune responses ( $\mathrm{N}$ and $\mathrm{HAl}$ ) derived from Babl/c mice inoculated with attenuated vaccine strains. Note: N, neutralization titre, taken as the highest dilution of serum to neutralize $50 \%$ of plaque numbers of homologous virus; $\mathrm{HAl}$, Haemagglutination inhibition titre, taken as the highest dilution of serum to inhibit $4 \mathrm{HA}$ units of homologous virus; NT, not tested.

\subsection{Protection efficacy}

Several studies have demonstrated that SA14-14-2 live vaccine induced high and broad protection against challenge by various JEV virulent strains in mice. Wang et al. [46] performed a study comparing the protective efficacy of 3 kinds of JE vaccine, the SA14-14-2 attenuated vaccine, the PHK derived P3 inactivated Vaccine (iPHKV) and the mouse brain purified inactivated Nak vaccine (MBV) in mice by i.p. inoculation with one dose of live vaccine, or 2 doses of the 2 kinds of inactivated vaccines respectively followed by i.p. challenge with 2 virulent JEV P3 and Nak strains. The results indicated that despite levels of neutralizing antibodies $(\mathrm{N})$ developed by the vaccination with live vaccine and MBV were equal at the day of pre-challenge, mice receiving the live vaccine were protected against the 2 challenging strains at higher rates than mice receiving the 2 inactivated vaccines (Table 14). Yu et al.[59] compared the immunogenicity of the SA14-14-2 live vaccine and PHKV in mice by i.p. vaccination followed by i.p. challenge with 14 wild strains isolated from different areas and years in China. The results indicated that live vaccine induced higher and broader protection levels than that induced by the iPHKV. In another study, Jia et al. [21] demonstrated that mice s.c. inoculated with a single dose of 34 or 340 pfu/mL SA14-14-2 virus, mice were protected (80-100\%) against i.p. challenge of the 22 JEV strains (11 isolated in China and the other 11 from Thailand, Vietnam, Indonesia, India, Philippines and Japan). 


\begin{tabular}{ccccccc}
\hline Vaccine & \multicolumn{2}{c}{$\begin{array}{c}\text { N titers at pre-challenge } \\
\text { against }\end{array}$} & \multicolumn{3}{c}{ P3 } & \multicolumn{3}{c}{ Nak } \\
\cline { 2 - 6 } & P3 & Nak & i.p. & i.c. & i.p. & i.c. \\
\cline { 2 - 6 } & $20^{a}$ & 40 & $10 / 10^{b}$ & $8 / 10$ & $10 / 10$ & $4 / 10$ \\
\hline SA14-14-2 & 10 & 5 & $7 / 10$ & ND & $5 / 10$ & ND \\
iPHKV P3 & 20 & 40 & $8 / 10$ & $3 / 10$ & $4 / 10$ & $1 / 10$ \\
\hline MBV(Nak) & ND & ND & $2 / 10$ & $1 / 10$ & $2 / 10$ & $3 / 14$ \\
\hline Control & & & &
\end{tabular}

Table 14. Protection of three kinds of JE vaccine in mice. Note: ND, Not determineda) Reciprocal of the highest dilution of serum that resulted in $50 \%$ reduction of plaque numbers.b) Number surviving challenge/number challenged i.p. intraperitoneally

\begin{tabular}{|c|c|c|c|c|c|c|c|}
\hline \multirow[t]{2}{*}{ No. } & \multirow{2}{*}{$\begin{array}{l}\text { Challenge } \\
\text { Virus strain }\end{array}$} & \multirow[t]{2}{*}{ Genotype } & \multicolumn{5}{|c|}{ Dose (pfu) } \\
\hline & & & 2340 & 234 & 23 & Control & $\begin{array}{l}\text { Challenge virus } \\
\text { dose }\left(\log _{10} L D_{50}\right)\end{array}$ \\
\hline 1 & SH-53 & 1 & $10 / 10^{a}$ & $10 / 10$ & $9 / 10$ & $2 / 10$ & 3.58 \\
\hline 2 & SH-101 & I & $10 / 10$ & $10 / 10$ & $10 / 10$ & $2 / 10$ & 3.17 \\
\hline 3 & LN02-102 & I & $10 / 10$ & $8 / 10$ & $4 / 10$ & $1 / 10$ & 3.84 \\
\hline 4 & SH03-127 & 1 & $10 / 10$ & $8 / 10$ & $7 / 10$ & $1 / 10$ & 3.71 \\
\hline 5 & HN04-11 & I & $10 / 10$ & $10 / 10$ & $5 / 10$ & $2 / 10$ & 2.75 \\
\hline 6 & SC04-17 & I & $10 / 10$ & $9 / 10$ & $10 / 10$ & $2 / 10$ & 4.00 \\
\hline 7 & SH05-24 & I & $10 / 10$ & $9 / 10$ & $4 / 10$ & $1 / 10$ & 3.77 \\
\hline 8 & $02-29$ & III & $10 / 10$ & $10 / 10$ & $7 / 10$ & $2 / 10$ & 3.50 \\
\hline 9 & $02-41$ & III & $10 / 10$ & $10 / 10$ & $6 / 10$ & $2 / 10$ & 4.50 \\
\hline 10 & HLJ02-134 & III & $9 / 9$ & $10 / 10$ & $6 / 10$ & $2 / 10$ & 2.88 \\
\hline 11 & HLJ02-144 & III & $10 / 10$ & $8 / 10$ & $4 / 10$ & $0 / 10$ & 3.00 \\
\hline 12 & DL04-06 & III & $10 / 10$ & $9 / 10$ & $9 / 10$ & $2 / 10$ & 3.24 \\
\hline 13 & P3 & III & $9 / 10$ & $9 / 10$ & $9 / 10$ & $1 / 10$ & 3.78 \\
\hline 14 & SA14 & III & $9 / 10$ & $9 / 10$ & $9 / 10$ & $1 / 10$ & 3.65 \\
\hline 15 & SA4 & III & $10 / 10$ & $10 / 10$ & $4 / 10$ & $2 / 10$ & 3.42 \\
\hline 16 & $\mathrm{KT}$ & III & $10 / 10$ & $9 / 10$ & $5 / 10$ & $1 / 10$ & 3.31 \\
\hline
\end{tabular}

Table 15. Protection efficacy of SA14-14-2 against intraperitoneal challenge with different heterologous JE virus strains. Mice were immunized with either 2340 pfu, 234 pfu or 23 pfu of SA14-14-2 virus;a) Number surviving challenge/number challenged.

However, since 1970's, a new genotype I of JEV has circulated in China while the genotype III JEV are still circulating in nature. In order to further categorize the degree of immunogenicity conferred by the SA14-14-2 vaccine against the both wild-type JEV genotypes (I and III) currently circulating in China. Liu et al [32] examined the protective efficacies of the SA14-14-2 live vaccine in mice by a single s.c.vaccination followed by i.p. challenge with 16 JEV isolates of the both genotype. As shown in Table 15,mice immunized with 2340 pfu of the live vaccine virus conferred an $80-100 \%$ protection rate against challenge with the 16 heterologous JE virus strains. Protection efficacy was $70-80 \%$ with vaccination dose as low as 234 pfu. 
This result was consistent with previous data indicating SA14-14-2 vaccine conferred strong and broad protections against JEV challenge[59][21].

\subsection{Suppression of viremia induction}

As shown in Table 16, guinea-pigs immunized with a single SA14-14-2 dose of $5.87 \mathrm{pfu} / \mathrm{mL}$ virus induced low neutralizing antibody levels( $<10$ by PRNT) 14 days after vaccination, but viremia was significantly suppressed in all vaccinated animals after i.p. challenge with P3 virulent JE strain compared to control animals in which all developed high levels of viremia (2.0-3.54 $\log _{10} \mathrm{pfu} / \mathrm{mL}$ ) that last 4 days. Interestingly, despite the neutralizing antibody levels of the vaccinated animals at the day of challenge (day0) were low, higher levels antibody developed rapidly beginning at day 4 post challenge compared to the control animals that developed slowly with low level antibodies beginning at day 7 post challenge [19].

\begin{tabular}{|c|c|c|c|c|c|c|c|c|c|c|c|c|c|}
\hline \multirow[t]{2}{*}{ Vaccine } & \multirow{2}{*}{$\begin{array}{l}\text { No. } \\
\text { testing }\end{array}$} & \multicolumn{5}{|c|}{ Viremia by day after challenge } & \multicolumn{7}{|c|}{ Titer of $\mathrm{N}$ antibody by day after challenge } \\
\hline & & 2 & 3 & 4 & 5 & 7 & 0 & 2 & 3 & 4 & 5 & 7 & 14 \\
\hline \multirow[t]{3}{*}{ SA14-14-2 } & 1 & $0 / 2^{a}$ & ND & ND & $0 / 2$ & $0 / 2$ & $<4-4^{c}$ & $<4-4$ & ND & ND & 256 & 1024 & 2048 \\
\hline & 2 & $0 / 3$ & $0 / 3$ & $0 / 3$ & ND & $0 / 3$ & $<4-16$ & $<4-16$ & $<4-16$ & $16-6$ & ND & $128-102$ & 4 1024-204 \\
\hline & & & & & & & & & & 4 & & & 8 \\
\hline \multirow{4}{*}{$\begin{array}{l}\text { None } \\
\text { (control) }\end{array}$} & 1 & $3 / 3$ & ND & ND & $0 / 3$ & $0 / 3$ & $<4$ & $<4$ & ND & ND & $<4$ & $<4-8$ & $32-64$ \\
\hline & & $(2.1-2.8)^{b}$ & & & & & & & & & & & \\
\hline & 2 & $4 / 4$ & $4 / 4$ & $2 / 2$ & ND & $0 / 4$ & $<4$ & $<4$ & $<4$ & $<4$ & ND & 8 & 128 \\
\hline & & $(2.0-2.7)$ & $(1.7-2.8)$ & (1.0- & & & & & & & & & \\
\hline
\end{tabular}

Table 16. Viremia suppression in guinea-pigs after vaccination with SA14-14-2 vaccine followed by challenge with virulent JEV. a, No. viremia positive/ no. tested; b,Viremia titre, $\log _{10} \mathrm{pfu} / \mathrm{mL}$; $c$, Reciprocal of the highest dilution of serum that resulted in $50 \%$ reduction of plaque numbers

\subsection{Evidence of cellular immune responses}

Several studies have shown evidence of cellular immunity induced by vaccination of SA14-14-2 vaccine in mice. Li et al.[28] studied the specific cytotoxic T lymphocyte (CTL) mediated immune responses in mice by vaccination with SA14-14-2 live vaccine and PHK inactivated vaccine. In the three testings, the average percentage of the specific CTL activity induced by mice vaccinated with one dose of live vaccine was higher $(79.2 \%)$ than the mice immunized with twice doses of the inactivated vaccine (29.0\%). Jia et al. [17] studied adoptive immunity in mice and demonstrated that mice received transfer of immune spleen cells from mice immunized with SA14-14-2 live vaccine was protected better (50\% protection) than that from mice immunized with 2 doses of inactivated vaccine (10\% protection).Another study was performed for examining the elicitation of cellular immunity by SA14-14-2 vaccine using an enzyme-linked immunospot (ELISPOT) assay. BALB/C mice were s.c. vaccinated with one dose of the live vaccine or 2 doses of a commercial SA14-14-2 inactivated PHK vaccine. Fourteen days after the initial immunization, mice were sacrificed and the the spleenocytes were isolated for detection of INF-@ and IL-2 spot forming cells (SFC) by 
ELISPOT assay. Serum samples were collected from the mice and pooled for detecting neutralizing antibody. Another group of immunized mice were i.p. challenged by virulent JEV P3 strains 14 days postvaccination. The results demonstrated that mice immunized with SA14-14-2 live vaccine produced more IFN- $\gamma$ SFC (89/10 cells) and IL-2 SFC (70-100/106 cells) than mice immunized with the inactivated vaccine $\left(<10 / 10^{6}\right.$ cells), respectively, the positive conversion rates of mice producing IFN- $\gamma$ and IL-2 SFC following the vaccination with live vaccine compared to the vaccination with inactivated were significant i.e, $100 \%$ and $100 \%$ vs $20 \%$ and $40 \%$ respectively. However, neutralizing antibody levels in mice following vaccination with the both vaccines were similar, but higher protection effects were observed for the live vaccine immunized mice (100\% vs $80 \%$ ) (Table 17) [26]. These data suggested the protection correlated better with cellular immunity than neutralizing antibody responses following live vaccine vaccination. Moreover, Li et al. [29] investigated the interaction of SA14-14-2 virus with mouse bone marrow-derived dendritic cells (bmDCs). The results showed that the infection of bmDCs with SA14-14-2 resulted in viral replication and upregulation of bmDCs maturation marker molecules(CD40,CD80,CD83 and MHC1). The infection also stimulated the production of interferon- $\alpha(\operatorname{IFN}-\alpha)$, monocyte chemoattractant protein-1 (MCP-1/CCL2), tumor necrosis factor- $\alpha$ (TNF- $\alpha$ ) and interleukin-6 (IL-6) of bmDCs. Furthermore, the SA14-14-2 infected bmDCs impaired the expansion of Foxp3+ regulatory $\mathrm{T}$ (Treg) cells with immunosuppressive potential, suggesting that SA14-14-2 infection induced antiviral immunity rather than immunosuppression. Taken together, the results indicated that SA14-14-2 infection caused bmDCs maturation, changed the expression profiles of several cytokines, and triggered $\mathrm{T}$ cell activation. This offered an insight in the immunologic mechanisms associated with the high efficacy of the SA14-14-2 vaccine.

\begin{tabular}{llllll}
\hline \multirow{2}{*}{ Vaccine } & \multirow{2}{*}{ Vaccinated dose $\left(\log _{10} \mathrm{pfu} / \mathrm{ml}\right)$} & \multicolumn{2}{l}{ ELISPOT assay } & Protection & NAb \\
\cline { 3 - 5 } & & IFN-r & IL-2 & \\
\hline SA14-14-2 & 6.31 & $10 / 10 \mathrm{a}$ & $10 / 10 \mathrm{~b}$ & $10 / 10 \mathrm{c}$ & $40 \mathrm{~d}$ \\
PHK live & 3.31 & $10 / 10$ & $10 / 10$ & $9 / 10$ & 40 \\
\hline SA14-14-2 & 2.31 & $9 / 10$ & $10 / 10$ & $5 / 10$ & 10 \\
inactivated & Undiluted & $2 / 10$ & $4 / 10$ & $8 / 10$ & 40 \\
\hline Control & - & $0 / 10$ & $0 / 10$ & $0 / 10$ & 10 \\
\hline
\end{tabular}

Table 17. Results of ELISPOT assay, protections and neutralizing antibody (NAb) responses in mice vaccinated with SA14-14-2 live and inactivated JE vaccines. a No. IFN- $p$ positive/no. tested mice; b No. IL-2 positive/no. tested mice; c No. survival/no. mice tested; $d$ Reciprocal of the highest dilution of serum that resulted in $50 \%$ reduction of plaque numbers

Recently, Zhang et al.[65] investigated cytokine and chemokine responses in humans recipients (34 subjects) of SA14-14-2 live attenuated vaccine, the results indicated that levels of interleukin (IL-8), monocyte chemoattractant protein (MCP)-1, macrophage inflammatory protein (MIP)- $\alpha$ and MIP-1 $\beta$ were significantly higher in the vaccinees than in a control group. IL- 6 was detectable in $64.7 \%$ of vaccinees, but was not detectable in any of the con- 
trols. Therefore, IL-6, IL-8, MCP-1,MCP- $1 \alpha$ and MIP- $1 \beta$ may play important roles in the immune response to JE live attenuated vaccine in the humans.

Besides Xu et al.[51] reported that mice immunized with SA14-14-2 virus non-structural NS1 protein, which expressed and purified from SA14-14-2 virus NS1 recombinant E.coli BL21 (DE3), were protected against a lethal JEV challenge (50-70\% protection). Guinea-pigs vaccinated with the NS1 protein presented with reduced viremia following challenge with virulent JE virus (Table 18)

\begin{tabular}{|c|c|c|c|c|c|c|c|c|}
\hline \multirow[t]{2}{*}{ Tested groups } & \multirow[t]{2}{*}{ No. animals } & \multicolumn{7}{|c|}{ Viremia $(\mathrm{pfu} / \mathrm{ml}$ ) by days postchallenge } \\
\hline & & 0 & 1 & 3 & 5 & 7 & 10 & 14 \\
\hline \multirow[t]{5}{*}{ SA14-14-2 NS1 } & 1 & $0 a$ & 0 & 0 & 0 & 0 & 0 & 0 \\
\hline & 2 & 0 & 0 & 0 & 0 & 0 & 0 & 0 \\
\hline & 3 & 0 & 0 & 2.5 & 0 & 0 & 0 & 0 \\
\hline & 4 & 0 & 7.5 & 20 & 0 & 0 & 0 & 0 \\
\hline & 5 & 0 & 17.5 & 145 & 15 & 0 & 0 & 0 \\
\hline \multirow{5}{*}{ Unimmunized controls } & 1 & 0 & 7.5 & $>579$ & 208 & 0 & 0 & 0 \\
\hline & 2 & 0 & 47.5 & 260 & 0 & 0 & 0 & 0 \\
\hline & 3 & 0 & 22.5 & 318 & 230 & 2.5 & 0 & 0 \\
\hline & 4 & 0 & 7.5 & 225 & 0 & 0 & 0 & 0 \\
\hline & 5 & 0 & 0 & $>750$ & ND & ND & ND & ND \\
\hline
\end{tabular}

Table 18. Viremia suppression in guinea pigs vaccinated with SA14-14-2 NS1 protein followed by challenge with virulent JEV. ND, Not determinedGuinea pigs were intraperitoneally (i.p.) vaccinated with NS1 protein, each 60 ug, at day 0 and 7 respectively. Fourteen days after the first vaccination, each vaccinated and unvaccinated animal was i.p. challenged with virulent JEV P3 strain (each $2.5 \mathrm{ml}$ ). a No virus detected in the undiluted serum

\section{Discussion}

Japanese encephalitis is a neuroinvasive virus, which is destructive of neural tissue. Loss of neurovirulence is an important consideration in live JE vaccine development. It is well known that the mice and Rhesus monkeys are highly sensitive animals for testing neurovirulence of JE virus. Both were used during development of live JE vaccine. The process of derivation of the SA14-14-2 strain has demonstrated fine balances between stable neuroattenuation and immunogenicity.

The principal issue surrounding the clinical application of the SA14-14-2 live virus vaccine candidate is safety, especially absence of neurovirulence and stable even passage in brain tissue. During development of the SA14-14-2 strain, it was demonstrated that unstable attenuated virus clones i.e. SA14-12-1-7 and SA14-12-1-1 could be detected by several passages in PHK cells or one i.c. mouse passage. Using this method, SA14-14-2 vaccine virus was selected for its neuroattenuation stability. To ensure vaccine safety, absence of neuroreversion after one ic passage in suckling mice is required in the quality control for vaccine production. 
Compared with other live attenuated viral strains, SA14-14-2 has the following characteristics:

1. Not temperature sensitive. During the course of attenuation the SA14 parental virus was cultured at $37^{\circ} \mathrm{C}$, while other live vaccine strains were cultured and passaged at lower temperature $\left(24^{\circ} \mathrm{C}\right.$ or $\left.32-35^{\circ} \mathrm{C}\right)$;

2. Homogeneity. SA14-14-2 strain exhibits as homogeneous small plaques and is stable after several tissue culture passages. The virus strain has been purified by 14 times by a plaque picking technique. Many licensed live vaccines were developed without clonal purification, i.e. the yellow fever 17D vaccine or insufficient purification, i.e. polio vaccine strains. It was reported that the yellow fever 17D vaccine and polio Sabin vaccine virus particles may be heterogeneous $[36,40]$, as they were not or insufficient cloned. The mixtures may contain neurovirulent virus particles;

3. Highly attenuated for experimental animals: SA14-14-2 strain is avirulent following inoculation by intracerebral or subcutaneous routes in 2.5-week old mice. Monkeys inoculated by the combination of intrathalamic and intraspinal routes developed no signs or death, and on histopathological examination, exhibited minor inflammatory reaction only along the needle track. While the yellow fever vaccine strain 17D, in world-wide use for 70 years, may cause up to $10 \%$ death in monkeys while lethal dose in an i.c. mouse test is as high as $3.0 \log _{10} \mathrm{LD} 50$. Also, polio vaccine viruses cause more histopathological lesions in monkeys than did SA14-14-2 virus;

4. Numerous substitutions of nucleotide and amino acid in the virus genome: mutation of virus genome is the molecular basis of attenuation. Molecular studies indicate that the SA14-14-2 vaccine strain differs from that of the virulent parental SA14 strain at 57-66 nucleotide locations resulting in 24-31 amino acid changes. The number of mutations observed is similar to the most stable Polio vaccine virus type I, with 56 nucleotide mutations resulting in 21 amino acid changes. Polio vaccine virus type III, which is unstable, has only 10 nucleotide mutations involving 2-3 amino acids. Polio virus type II, has 23 nucleotide mutations, also fewer than SA14-14-2. More than 70\% Vaccine Associated Paralytic Poliomyelitis has been caused by Type III polio vaccine virus, which has the fewest amino acid changes from parental virus [40].

As for the immunogenicity of the SA14-14-2 vaccine, studies have demonstrated that protection efficacy of the live attenuated vaccine was mediated by the presence of neutralizing antibodies and by potent cell-mediated immunity as well as the NS1 protein induced immunity, which associated with the high efficacy of the SA14-14-2 vaccine. Besides anamnestic immune response will give quick rise of neutralizing antibody and provide long-term protection against JE infection among subjects who become seronegative after immunization with SA14-14-2 live vaccine [39]

Live JE vaccine (SA14-14-2) has been used in more than 300 million children since large scale production began in 1989. To date no vaccine associated JE cases has been reported in China and outside.The safety of live JE vaccine is due to a high degree of neuroattenuation and a number of stable phenotypic and genotypic characteristics. The combination of lack of viremia in the vaccinees and the absence of virus replication and dissemination in the mosquito 
vector make the likelihood of transmission of JE vaccine virus and the risk of environment highly unlikely. Therefore the exceptional safety, stability, immunogenicity and long-term protective efficacy present a strong case for the expended use of this live attenuated JE vaccine in the world.

\section{Author details}

Yongxin $\mathrm{Yu}^{*}$

Address all correspondence to: yuyongxin@nicpbp.org.cn

Department of Arbovirus Vaccines, National Institutes for Food and Drug Control, P.R. China

\section{References}

[1] Aihara, S., Rao, C. M., Yu, Y. X., Lee, T., Watanabe, K., Komiya, T., et al. (1991). Identification of mutations that occurred on the genome of Japanese encephalitis virus during the attenuation process. Virus Genes, 5, 95-109.

[2] Ao, J., Yu, Y. X., Wu, H. Y., Wu, P. F., Wang, Z. W., \& Zhang, G. M. (1983). Selection of a better immunogenic and highly attenuated live vaccine virus strain of Japanese encephalitis II. Safety and immunogenicity of live JE vaccine SA14-14-2 observed in inoculated children. Chin J Microbiol Immunol, 3, 245-248.

[3] Arroyo, J., Guirakhoo, F., Fenner, S., Zhang, Z. X., Monath, T. P., \& Chambers, T. J. (2001). Molecular basis for attenuation of neurovirulence of a yellow fever virus/ Japanese encephalitis virus chimera vaccine (ChimeriVax-JE). J Virol, 934-942.

[4] Bista, M. B., Banerjee, M. K., Shin, S. H., Tandan, J. B., Kim, M. H., \& Sohn, Y. M. (2001). Efficacy of single-dose SA14-14-2 vaccine against Japanese encephalitis: a case control study. Lancet, 358(9284), 791-5.

[5] Chen, P. Q., Zhou, B. L., Ma, W. X., et al. (1992). study on the epidemiological efficacy of live Japanese encephalitis vaccine (SA14-14-2). Chin J Biologicals, 5, 135-7.

[6] Chotpitayasunondh, T., Sohn, Y. M., Yoksan, S., et al. (2011). Immunizing children aged 9 to 15 months with live attenuated SA14-14-2 Japanese encephalitis vaccine in Thailand. J Med Assoc Thai, 94(3), s195-s197.

[7] Eckels, K. H., Yu, Y. X., Dubois, D. R., Marchett, N. J., Trent, D. W., \& Johnson, A. J. (1988). Japanese encephalitis virus live-attenuated vaccine, Chinese strain SA14-14-2; adaptation to primary canine kidney cell cultures and preparation of a vaccine for human use. Vaccine, 6, 513-8. 
[8] Fan, X. L., Yu, Y. X., Li, D. F., \& Yao, Z. H. (2002a). Comparison of nucleotide and deduced amino acid sequences of E protein gene of the wild-type Japanese encephalitis virus strain SA14 and its different attenuated derivatives. Virologica Sinica, 17, 216-220.

[9] Fan, X. L., Yu, Y. X., Li, D. F., \& Yao, Z. H. (2002b). The stability of E protein gene of the Japanese encephalitis live-attenuated vaccine virus SA14-14-2. Chin J Virology, 18, 39-47.

[10] Feng, Y., Zhang, H. L., Yu, Y. X., Zhang, Z. Y., Yang, W. H., Dong, G. M., et al. (2007). Observations on the replication of virus and stability of virulence in Culex tritaeniorhynchus after intrathoracically inoculation with attenuated Japanese encephalitis virus SA14-14-2 vaccine strain. Chin J Zoonoses, 23, 278-281.

[11] Gao, X. J., Zhao, Y. J., Liu, C. M., Zou, Y., Wei, Y., Zheng, X. G., et al. (2006). The stability of E gene of the Japanese encephalitis attenuated virus strain SA14-14-2. Prog in Microbiol Immunol, 34, 1-11.

[12] Gatchalian, S., Yao, Y., Zhou, B., et al. Comparison of the immunogenicity and safety of measles vaccine administered alone or with live, attenuated Japanese encephalitis SA14-14-2 vaccine in Philippine infants [J]. Vaccine, 26(18), 2234-2241.

[13] Guirakhoo, F., Zhang, Z. X., Chambers, T. J., Delagrave, S., Arroyo, J., Barrett, A. D. T., et al. (1999). Immunogenicity, genetic stability, and protective efficacy of a recombinant, chimeric yellow fever-Japanese encephalitis virus (ChimeriVax-JE) as a live, attenuated vaccine candidate against Japanese encephalitis. Virology, 257, 363-372.

[14] Hennessy, S., Liu, Z. L., Tsai, T. F., et al. (1996). Effectiveness of live-attenuated Japanese encephalitis vaccine (SA14-14-2): a case control study. Lancet, 347, 1583-87.

[15] Huang, Z. L., Li, X. G., \& Wu, J. N. (1998). Observation on the side reaction after vaccination with Japanese encephalitis live vaccine. Chin J Zoonoses, 14, 60-61.

[16] Jia, L. L., Zheng, Z., \& Yu, Y. X. (1992). Study on the immune mechanism of JE attenuated live vaccine(SA14-14-2 strain). Chin J Microbio Immuno, 12, 364-366.

[17] Jia, L. L., Zheng, Z., Guo, Y. P., \& Yu, Y. X. (1992). Stability of live-attenuated Japanese encephalitis vaccine strain SA14-14-2. Chin J Biologicals, 5, 174-6.

[18] Jia, L. L., Zheng, Z., \& Yu, Y. X. (1993). Pathogenicity and Immunogenicity of attenuated Japanese encephalitis vaccine (SA14-14-2) in immune-inhibited mice. Virologica Sinica, 8, 20-4.

[19] Jia, L. L., Zheng, Z., Wang, Z. W., et al. (1995a). Protective effect and antibody response in guinea-pigs immunized with Japanese encephalitis attenuated live vaccine after challenge with virulent virus. Prog Microbiol Immunol, 23, 73-76. 
[20] Jia, L. L., Zheng, Z., Yu, Y. X., et al. (1995b). Neutralizing antibody response of Japanese encephalitis live vaccine in children residing in JE endemic area. Chin J, 11, 343-4.

[21] Jia, L. L., Yu, Y. X., Tsai, T. F., et al. (2000). Immunity of live attenuated Japanese encephalitis (JE) vaccine to different wild JE virus strains. Chin J Biologicals, 13, 208-210.

[22] Jia, L. L., Yu, Y. X., Huang, Ying., Wang, Z. W., Yue, G. Z., Zheng, Z., et al. (2004). Stability of phenotype and E Protein gene of primary virus seed and final product of live attenuated Japanese encephalitis vaccine. Chin J Biologicals, 17, 12-5.

[23] Kumar, R., \& Rizvi, A. (2009). Effectiveness of one dose of SA14-14-2 vaccine against Japanese encephalitis. N Engl J Med, 360, 4465-66.

[24] Komiya, Lee T., Watanabe, K., et al. (1995). Immune response in mice infected with the attenuated Japanese encephalitis vaccine strain SA14-14-2. Acta Virologica, 39, 161-164.

[25] Li, H. M., Yu, Y. X., Ao, J., \& Fong, T. (1966). Studies on the variation of Japanese encephalitis virus : the pathogenicity and immunogenicity of SA14-A clone viruses. Acta Microbiologica Sinica, 12, 41-49.

[26] Li, M. G., Yu, Y. X., Liu, X. Y., Xu, H. S., Jia, L. L., Wang, Z. W., et al. (2010). Comparative study on the cellular immune response induced by live attenuated SA14-14-2 Japanese encephalitis vaccine and inactivated Japanese encephalitis vaccine in mice. Chin J Vaccines Immunization, 16(4), 339-44.

[27] Li, Y. H., Liu, J., Wang, W., Niu, J. C., Wu, Y. L., Liu, R., et al. (2003). Study of the genetic stability of Japanese encephalitis attenuated virus strain SA14-14-2 after passaging on primary hamster kidney cells. Chin J Biologicals, 16, 333-335.

[28] Li, Y. L., Li, S. Y., Wang, H. B., et al. (1999). Comparison of antibody and cell-mediated immune responses induced by live attenuated and inactivated Japanese encephalitis vaccine in mice. Chin J Biologicals, 12, 229-230.

[29] Li, Y. M., Ye, J., Yang, X. H., et al. (2011). Infection of mouse bone marrow-derived dendritic cells by live attenuated Japanese encephalitis virus induces cells maturation and triggers T cells activation. Vaccine, 29, 855-862.

[30] Ling, J. P., Zhu, Y. G., Du, G. Z., Lang, S. H., Jia, L. L., \& Yu, Y. X. (2000). Comparison of pathogenicity and pathology between wild Japanese encephalitis virus SA14 and attenuated strain SA14-14-2 in Rhesus monkey and mouse models. Progress in Microbiology and Immunology, 28, 1-4.

[31] Liu, X. Y., Yu, Y. X., Xu, H. S., et al. (2010). Comparison of viremia formation between guinea-pigs infected with wild and attenuated (SA14-14-2) Japanese encephalitis viruses. Chin J Exp Clin Virol, 24, 343-5. 
[32] Liu, X. Y., Yu, Y. X., Li, M. G., et al. (2011). Study on the protective efficacy of SA14-14-2 attenuated Japanese encephalitis against different JE virus isolates circulating in China. Vaccine, 29, 2127-2130.

[33] Liu, Z. L., Hennessy, S., Strom, B. L., Tsai, T. F., Wan, C. M., \& Tang, S. C. (1997). Short-term safety of live attenuated Japanese encephalitis vaccine (SA14-14-2): results of a randomized trial with 26,239 subjects. J Infect Dis, 176, 1366-9.

[34] Liu, Z. W., Yu, Y. X., Zhang, H. L., Wang, Z. W., Jia, L. L., Zhang, Z. Y., et al. (2007). Biological and molecular characteristics of live attenuated Japanese encephalitis vaccine virus strain SA14-14-2 inoculated intrathoracically to Culex tritaeniorhynchus. Chin J Biologicals, 20, 419-421.

[35] Yu, W. X., Wang, Y. X., Zhou, S. G., Ma, B. L. Y. H., Feng, S. Y., et al. (1993). Observation of safety and serological efficacy from large-scale field trial on Japanese encephalitis live vaccine. Chin J Biologicals, 6, 188-191.

[36] Monath, T. P. (2004). Yellow fever vaccine. In: Plotkin SA, Orenstein WA, editors. Vaccines.4th ed. USA: Saunders, 667-670.

[37] Burns, N. I. H., Chang, N. J., -J, G., Zhang, J., Wills, M. R., Trent, D. W., et al. (1994). Comparison of nucleotide and deduced amino and sequence of non-coding regions and structural protein genes of the wild-type Japanese encephalitis virus strain SA14 and its attenuated vaccine derivatives. J gen virol, 75, 1505-1510.

[38] Sohn, Y. M., Park, M. S., Rho, H. O., Chandler, L. J., Shope, R. E., \& Tsai, T. F. (1999). Primary and booster immune responses to SA14-14-2 Japanese encephalitis vaccine in Korean infants. Vaccine, 17, 2259-64.

[39] Sohn, Y. M., \& Tandan, J. B. (2008). A 5-year follow- up of antibody response in children vaccinated with single dose of live attenuated SA-14-14-2 Japanese encephalitis vaccine: Immunogenicity and anamnestic responses [J]. Vaccine, 26, 1638-43.

[40] Sutter, R. W., \& Cochi, S. L. (2004). Live attenuated poliovirus vaccine. In: Plotkin SA, Orenstein WA, editors. Vaccines. 4th ed. USA: Saunders, 667-670.

[41] Tandan, J. B., Ohrr, H., Sohn, Y. M., Yoksan, S. Jim, Nam, C. M., et al. (2007). Single dose of SA14-14-2 vaccine provides long-term protection against Japanese encephalitis: A case-control study in Nepalese children 5 years after immunization. Vaccine, 25, 5041-5045.

[42] Tang, W. G., Zhao, D. H., Zhou, S., et al. (2003). A case control study on the effectiveness of live attenuated Japanese encephalitis vaccine. Chin J Vaccines Immunization, 9, 213-4.

[43] Wang, J. R., Na, J. Q., Zhao, S. S., et al. (1993). Study on the epidemiological efficacy of live Japanese encephalitis vaccine. Chin J Biological, 6, 36-37. 
[44] Wang, S. G., Yang, H. J., Deng, Y. Y., Wang, F. B., Zheng, Q. W., \& Yu, Y. X. (1990). Studies on the production of live-attenuated Japanese encephalitis vaccine SA14-14-2. Chin J Virology, 6, 38-43.

[45] Wang, S. G., Yu, Y. X., Zheng, Q. W., Zhang, D. Q., Jia, L. L., \& Li, Y. H. (1992). Study on adaption of attenuated Japanese encephalitis virus strain (SA14-14-2 PHK) to primary fetal dog kidney cell cultures. Chin J Biologicals, 5, 49-51.

[46] Wang, Z. W., Jia, L. L., Yue, G. Z., et al. (1999). Study on the comparison of protective effect in mice with three kinds of JE vaccine made in China and Japan. Chin J Public Health, 18, 69-71.

[47] WHO Technical Report Series No.910. (2002). Guidelines for the the production and control of Japanese encephalitis vaccine (live) for human use. In: WHO Expert Committee On Biological Standardization, Fifth-first report. Geneva.World Health Organization. Annex 3.

[48] Wills, M. R., Singh, B. K., Debnath, N. C., et al. (1993). Immunogenicity of wild-type and vaccine strains of Japanese encephalitis virus and the effect of haplotype restriction on murine immune responses. Vaccine, 11, 761-6.

[49] Wu, Y. L., Liu, J., Yang, H. Q., Zhao, N., Mou, J. C., Huang, Y. X., et al. (2007). Genetic property of attenuated Japanese encephalitis virus strain SA14-14-2 after subculture in suckling mouse brain. Chin J Biologicals, 20, 19-21.

[50] Wu, Y. L., Zhou, Y., Huang, Y. X., et al. (2007). Dynamic distribution of attenuated Japanese encephalitis virus strain SA14-14-2 in mice. Chin J Biologicals, 20, 204-5.

[51] Xu, H. S., Yu, Y. X., Jia, L. L., Huang, Y., Dong, G. M., \& Yu, W. Y. (2010). Prokaryotic expression and immunogenicity of NS1 and E proteins of Japanese encephalitis virus SA14-14-2 strain. Chin J Biol, 23(2), 118-23.

[52] Xu, L. Y., Xu, W. Q., Xu, F. H., Wang, B., \& Zhang, X. J. (2008). Biological and genetic stability of attenuated Japanese encephalitis vaccine virus strain SA14-14-2. Chin J Biologicals, 21, 833-837.

[53] Yu, Y. X., Ao, J., Lei, W. X., \& LI, H. M. (1962). Studies on the variation of Japanese encephalitis virus: Pathogenicity and immunogenicity in mice and monkeys after serial passages in primary hamster kidney cells. Acta microbiologica Sincica, 8, 260-269.

[54] Yu, Y. X., Ao, J., Zhu, Y. G., Fong, T., Huang, N. J., \& Liu, L. H. (1973). Studies on the variation of Japanese encephalitis virus. V. The biological characteristics of an attenuated live vaccine virus strain. Acta Microbiologica Sinica, 13, 16-24.

[55] Yu, Y. X., Wu, P. F., Ao, J., \& Liu, L. H. (1981). Selection of a better immunogenic and highly attenuated live vaccine virus strain of Japanese B encephalitis I. Some biological characteristics of SA14-14-2 mutant. Chin J Microbiol Immunol, 1, 77-83. 
[56] Yu, Y. X., Wang, J. F., Zhuang, G. M., \& Li, H. M. (1985). Response of normal and athymic mice to infection by virulent and attenuated Japanese encephalitis viruses. Chin J Virology, 1, 20-39.

[57] Yu, Y. X., \& Wang, J. F. (1986). In vitro Characteristics of attenuated Japanese encephalitis viruses. Chin J Virology, 2, 197-201.

[58] Yu, Y. X., Zhang, G. M., Guo, Y. P., Ao, J., \& Li, H. M. (1988). Safety of a live-attenuated Japanese encephalitis virus vaccine (SA14-14-2) for children. Am J Trop Med Hyg, 39, 214-217.

[59] Yu, Y. X., Zhang, G. M., \& Zheng, Z. (1989). Immunogenicity of live and killed Japanese Encephalitis (JE) vaccine to challenge with different Japanese Encephalitis virus strains. Chin J Virology, 6, 106-10.

[60] Yu, Y. X., Ma, W. X., Jia, L. L., Jiang, X. K., Wang, H. Q., \& Yue, G. Z. (1994). Clinical and serological studies of Japanese encephalitis live vaccine, SA14-14-2 PDK strain, in humans. Chin J Biologicals, 7, 52.

[61] Zeng, M. Y. U. Y. X., Dong, G. M., Jia, L. L., Yao, Y. F., \& Li, D. F. (2001). Sequence analysis of the full-length genome of Japanese encephalitis virus vaccine SA14-14-2. Chin J Microbiol Immunol, 21, 535-9.

[62] Zhang, Y. Z., Zhang, H. L., Yu, Y. X., Feng, Y., Dong, G. M., Yang, W. H., et al. (2005a). Studies on Culex tritaeniorhynchus and Culex pipiens quinquefascitatus infected orally by Japanese encephalitis SA14-14-2 vaccine virus. Chin J Zoonoses, 21, 584-591.

[63] Zhang, Y. Z., Zhang, H. L., Yu, Y. X., Feng, Y., Dong, G. M., Yang, W. H., et al. (2005b). Research on Culex tritaeniorhynchus and Culex pipiens quinquefascitatus intrathoracically infected with attenuated Japanese encephalitis virus SA14-14-2 vaccine strain. Chin J Exp Clin Virol, 19, 344-346.

[64] Zhang, H. R., Wang, L. Y., Chen, L. J., et al. (2002). Analysis on the immune effects and safety of the live attenuated and inactivated Japanese encephalitis vaccines. Chin J Vaccines Immunization, 8, 248-50.

[65] Zhang, J. S., Zhao, Q. M., Zuo, S. Q., et al. (2012). Cytokine and chemokine responses to Japanese encephalitis live attenuated vaccine in a human population. International J Infectious Disease, 16, 285-288.

[66] Zhou, B. L., Jia, L. L., Xu, X. L., Wang, H. M., Cai, Z. Y., Zhang, Z. J., et al. (1999). A large-scale study on the safety and epidemiological efficacy of Japanese encephalitis (JE) live vaccine (SA14-14-2) in the JE endemic areas. Chin J Epidemiol, 20, 38-41.

[67] Zhou, B. L., Zhang, M., Chen, P. Q., Jiang, X. K., Zhang, L. B., Quan, B. H., et al. (2001). An 11 years follow-up of epidemiological effect of live attenuated Japanese encephalitis vaccine (SA14-14-2). Chin J Biologicals, 14, 183-185. 
[68] Zhu, Y. G., Li, H. M., \& Zang, X. (1966). Pathology of attenuated Japanese encephalitis virus. Chin J Pathology, 10, 113-6. 